\title{
Should Voters Care More about Policy than Character?
}

\author{
Verlan Lewis \\ Assistant Professor \\ Department of Political Science \\ University of Colorado \\ Colorado Springs \\ ph: 719-255-4008 \\ verlanlewis@gmail.com
}

\begin{abstract}
The dominant political science models of voting portray rational voters as casting their votes based on which candidate is closest to the voter's ideal policy preference points. This model assumes that voters care more about policy outcomes they think a candidate will enact while in office than a candidate's character or leadership qualities (and that voters have, ex ante, ideal policy preference points that they can rationally compare with the ideal policy preference points signaled by the candidates). Certainly, if we look at recent presidential elections, it seems that, among both primary voters and general election voters, many are willing to "hold their nose" and vote for the candidate seemingly closest to their policy preferences. This article asks whether rational voters should behave this way or not by examining whether ideological signals provided in the presidential campaign are predictive of legislation enacted. Specifically, this article examines the important laws passed over the last thirty years to see if the content of this legislation moved public policy in the direction of the supposed policy preferences of the elected president.
\end{abstract}

Keywords: American Politics; Public Policy; Ideology; Presidents; Political Parties; Voting 


\section{Introduction}

Imagine Hillary Clinton had been elected president in 2016 instead of Donald Trump. In this counter-factual situation, imagine that in March 2020 President Clinton's administration responds to the Covid-19 pandemic, in consultation with a Democratic House of Representatives, with a proposed $\$ 2.2$ trillion stimulus package after already increasing U.S. federal debt by an astounding $\$ 2$ trillion during her first term. What, might we guess, would be the reaction from a Republicancontrolled Senate? While we can never know exactly what would have happened in this alternate universe, it is likely that Republicans in Congress would have opposed such a proposal as a form of “socialism," "big government," "fiscal recklessness," "welfare state spending," and a "government bailout." After all, that is how Republican MCs have usually responded to much smaller spending proposals by Democratic presidents over the past century. A $\$ 2.2$ trillion spending proposal, dwarfing anything previously seen in American history, would have likely generated a similar reaction to what happened in 2009 with the Tea Party's opposition to government spending and debt during the Obama administration. Given the GOP's control of the U.S. Senate, it is unlikely that any such proposal would ever have made it through Congress and onto the president's desk. In this counter-factual situation, the largest government spending bill in American history (the CARES Act) would have never become law. Ironically, it is only because "the party of small government" controlled the presidency that the size of the federal government increased dramatically in the spring of 2020 .

While this situation may be puzzling, it is actually not unique-it has characterized much of American history. When we examine the history of American legislation, we find that important laws are often written and passed by the opposite political party from the one voters, prospectively, would have expected to pass such legislation. This surprising fact runs counter to the common view 
among voters that they should cast their vote for the candidate who promises to be, or has the reputation for being, closest to the voter's ideal preference point. It also runs counter to the dominant theories of legislative politics in the United States. When we consider this fact, we need to re-think the way that most people, including both voters and political scientists, view American voting and policymaking.

The dominant models of U.S. lawmaking theorize that, during a political campaign, voters have fixed policy preference points, and that parties and candidates move around in policy space to capture the largest number of votes possible based on the fixed locations of voter preference points. ${ }^{1}$ After the election, according to this "master theory" of American politics (Fiorina \& Abrams, 2009, p. xvii), parties and politicians bring their preference points into office, and the legislation they produce is determined by how the locations of their spatial preferences interact with their institutional contexts. ${ }^{2}$ While scholars debate the relative importance of ideology and party in determining how much legislation is enacted by the national government, the shared assumption is that officeholders largely enact the policies we would expect from the policy signals their party communicated in the campaign. ${ }^{3}$

In this view of policymaking, the policy preferences of the party that controls the presidency matters a great deal for the substantive content of legislation. Aside from the rare veto override, the party that controls the presidency can ensure that only bills that move the public policy status quo in the direction the party desires will be signed into law. If this is true, then voters are perhaps rational when they vote for the presidential candidate whose preference points are closest to their own even if that candidate is a demagogue or authoritarian who threatens to undermine democracy itself (Sladin \& Teles, 2020, p. 7).

\footnotetext{
${ }^{1}$ For a review of this literature, see Hinich \& Munger (1994).

${ }^{2}$ For a review of this literature, see Hacker \& Pierson (2014).

${ }^{3}$ For a review of this literature, see Grossman (2014)
} 
This paper tests that political science theory of lawmaking, and that "hold-your-nose" justification of vote choice, by examining the kind of legislation enacted over the past thirty years to see if important laws really do move public policy in the direction supposedly desired by the party in control of the presidency. I find that, in reality, important legislation more often moves public policy in the direction of the losing presidential party's preferences than the victorious presidential party's preferences. Presidents may not be the decisive legislative pivots that political scientists have long thought, and voters may not be gaining as much in policy as they think when they "hold their nose" and vote for corrupt and authoritarian candidates.

\section{Important Laws and the Presidency since 1989}

To identify the most important national laws that have been enacted over the past thirty years, I rely on David Mayhew's well-known database (Mayhew, 2019). I code each of these 169 laws as moving public policy in the direction of the policy preferences signaled by the most recent victorious presidential candidate, the losing presidential candidate, or neither (see Appendix 1). To make these coding decisions, I compared the content of each important law with the reputation of the parties and the presidential candidates as presented in the most recent presidential campaign before the law was enacted.

To give the reader a sense of how I made these coding decisions, I will give an example of each of the three coding possibilities. I coded the minimum wage hike of 1989, signed into law by President George H.W. Bush, as moving public policy more in the direction of the preferences signaled by the Democratic Party and their losing candidate in the 1988 presidential campaign (Michael Dukakis) than in the direction of the preferences signaled by the Republican Party and their victorious candidate because, in 1988, the Democratic Party and Dukakis had a reputation as being in favor of raising the minimum wage and the Republican Party and Bush did not. I coded the 2001 
Bush Tax Cut as moving public policy more in the direction of the preferences signaled by the Republican Party and their victorious candidate in the 2000 presidential campaign than in the direction of the preferences signaled by the Democratic Party and their losing candidate (Al Gore) because, in 2000, the Republican Party and Bush had a reputation as being in favor of cutting income taxes and the Democratic Party and Gore did not. Finally, I coded the Bipartisan Tax Deal of 2010 as neither moving public policy in the direction of the victorious presidential candidate (Obama) or the losing presidential candidate (McCain) because this piece of compromise legislation could feasibly be seen as supporting either major party's policy preferences. On the one hand, the law extended the Bush tax cuts, which supported the policy preferences signaled by the Republican Party and McCain, but on the other hand, the law also extended federal unemployment insurance benefits, which supported the policy preferences signaled by the Democratic Party and Obama.

Of the 169 important laws enacted during the $101^{\text {st }}$ through $115^{\text {th }}$ Congresses, I found that 64 moved public policy in the direction of the policy preferences signaled by the losing presidential candidate, 56 moved public policy in the direction of the policy preferences signaled by the winning presidential candidate, and 49 did not clearly move public policy in the direction of either candidate's position. Less than one-third of important laws moved public policy in the direction presumably desired by those who voted for the winning candidate. Of the 120 laws that clearly moved public policy one way or the other, public policy more often moved in the direction of the losing candidate's position than the winning candidate's position. In sum, voters who win a presidential election contest do not always get what they want. In fact, in terms of important legislation, voters are more likely to get the policy they want by losing a presidential election than by winning a presidential election. How can this be? 


\section{Divided Government and Public Policy}

The most obvious explanation for this counter-intuitive finding is that the period since 1989 has been characterized by divided government: Between the $101^{\text {st }}$ and the $115^{\text {th }}$ Congresses, ten governments were divided while only five were unified. Thus, a partial explanation for presidential irrelevance is that the House of Representatives and Senate can often move public policy in the direction they want in spite of opposition from the president who won the election. If the party that loses the presidency wins control of Congress, they can still sometimes bully the president into signing what they want.

However, this is only a partial explanation. Presumably, wielding the veto pen under divided government, the president should be able to work with Congress to enact laws that move public policy in their preferred direction at least as often as they enact laws that move public policy in the direction preferred by Congress. Surprisingly, this is not what happens. Of the 90 major laws passed by a unified Congress opposed to a president from the other party, 23 moved policy in the direction of the presidential party's preferences and 40 moved policy in the direction of the preferences signaled by the Congressional party during the campaign. In this situation, where we might expect an even draw, it seems that Congress has the decisive upper hand. We might conclude from this that, in the American political system, a unified Congress wields more power than a unitary executive when it comes to the legislative arena (at least when it comes to the kind of legislation that is signed by both Congress and the president).

Perhaps, instead, the real legislative power of the president can be seen when Congress is divided against itself: when the two houses of Congress are controlled by different parties. However, even in these circumstances, the president's party fails to prevail. Of the 33 major laws passed by a divided Congress and signed by the president, 14 laws moved policy in the direction of the minority party and only 6 laws moved policy in the direction of the president's party. Thus, if Congress is 
divided between the two parties, the party that controls the presidency paradoxically gets less of what it wants than the opposition party.

The one scenario where we would expect the president's party to prevail unambiguously is under unified government, and it is true that the president's party fares much better under unified government than divided government, but not always. Of the 46 major laws enacted by unified government, only 27 of them clearly moved public policy in the expected direction. 9 laws did not move public policy in either direction and, even more surprisingly, 10 of the major laws moved public policy in the direction of the preferences signaled by the party completely shut out of the government. For example, the Republican Party in control of unified government during the administration of Bush 43 enacted several important laws that moved public policy in the direction of the Democratic Party's preferences, including expanding Medicare benefits and AIDS spending. Why would a Republican Congress and a Republican president choose to increase, rather than decrease, federal spending on social programs when they campaign on promises to shrink, not expand, the size of government? Republicans in Congress had opposed Medicare Part D when it was proposed by Democratic President Clinton but passed it when it was proposed by Republican President Bush. Is a change in ideological ideal preference points (Republican MCs moving to the "left" in the 2000s) really the most useful way to think about what happened?

Furthermore, why does the president's party seem to lose so often during periods of divided government? For example, the $104^{\text {th }}$ Congress was quite productive under the leadership of Speaker of the House Newt Gingrich (R-GA), and convinced the Democratic President Bill Clinton to sign many of its public policy preferences into law, including welfare reform, telecommunications reform, spending cuts, and immigration restrictions. Why wouldn't a president simply veto bills that move policy in the direction of their opponents? What explains these outcomes? 


\section{Ideology and Public Policy}

To the extent that they have addressed this question at all, political scientists have mostly relied on spatial models of ideology, and argue that ideology is more important than party in explaining legislative outcomes (Krehbiel, 1998). In this view, all voters, legislators, executives, and judges can be arrayed in ideological space, and that most of the time a uni-dimensional "left-right" spectrum is adequate to describe their ideological ideal-point preferences (Poole \& Rosenthal, 2006). In this explanation, presidents are often stifled not only by the opposing party but also by "centrist" co-partisans in Congress who, like their colleagues in the opposition party, prefer the status quo to moving policy to the "left" or "right" as desired by the president. Keith Krehbiel, for example, emphasizes the defection of "liberal" Republicans and "conservative" Democrats, who prefer the status quo and reside in the "gridlock zone," as the reason that the national government does not, all of a sudden, start producing much more legislation when shifting from divided to unified government (1998).

Although he does not address this in-depth in his book, Krehbiel's "pivotal politics" theory could also, presumably, explain presidents signing legislation moving public policy in the preferred direction of the opposition party. According to this model of policymaking, if the president is a "centrist" Democrat and the status quo resides on the extreme "liberal" end of the spatial distribution of legislator preference points, then they would join with all the "conservatives" and "centrists" in Congress to sign legislation moving policy "to the right" towards the "center."

Conversely, if the president is a "centrist" Republican and the status quo resides on the extreme "conservative" end of the spatial distribution of preference points, then they would join with all the "liberals" and "centrists" in Congress to sign legislation moving policy "to the left." Thus, a Democratic Congress and a Republican president (e.g., Bush 41) can move the public policy status quo marginally in the Democratic Party's preferred direction as long as the Republican president 
wants to move the status quo marginally in that direction, too (even if the president does not want to go as far as the Democratic Congress would have ideally wanted to go). Or, a Republican Congress and a Democratic president (e.g., Clinton) can move the public policy status quo marginally in the Republican Party's preferred direction as long as the Democratic President wants to move the status quo marginally in that direction, too (even if the president does not want to go as far as the Republican Congress would have ideally wanted to go). In fact, even a Republican Congress and a Republican president (e.g., Bush 43) could move the public policy status quo marginally in the Democratic Party's direction as long as they both want to move the status quo marginally in that direction (even if it is not as far as the opposition Democrats would have ideally wanted them to go). In this model of policymaking, ideology—and not party—is the real explanation of why important laws move the public policy status quo the way that they do.

This explanation runs into a couple major problems. First, these theories are usually presented in such a way that they are not falsifiable. The independent variable (the ideological preference points of legislators) and the dependent variable (the ideological content of legislation) are both calculated based on the same observed behavior (roll-call votes). Regardless of how a policymaker votes, their vote is explained by their ideological ideal preference point "revealed" by their vote (Poole \& Rosenthal, 2006). Thus, we cannot be surprised by Bush 43 signing laws that expanded Medicare spending and AIDS spending. Since Bush 43 was a "conservative" president, those laws must have been "conservative." In this model of policymaking, there is no way for a policymaker to signal one set of ideological preferences in the campaign and vote to promote a different set of ideological preferences when in office. The claim that policymakers act on their ideological preference points, in this approach, is tautological and not falsifiable.

Second, if we instead independently identify a legislator's policy preferences (e.g., by looking at their rhetoric) and their votes, we find that policymaker's often vote contrary to their professed 
ideology. "Conservative" Republicans criticized the Democratic Party's "liberal" plans to expand Medicare spending proposed by Clinton, but those same "conservatives" voted for that policy when it was proposed by Bush 43. "Conservative” Republicans (including George W. Bush) criticized the Clinton administration's foreign interventionism in the 1990s, but those same "conservatives" supported the Bush administration's foreign interventionism in the 2000s. "Tea Party" Republicans (including Donald Trump) criticized the Obama administration's federal spending and deficits in 2009 and 2010, but those same "conservatives" supported the Trump administration's massive deficit spending a few years later. The few "conservative" MCs who refused to drastically change their policy preferences to rationalize the actions of the Republican president (e.g., Jeff Flake) are now considered "squishy liberals," "RINOs" and moderates (Hopkins \& Noel, 2017) even though their policy preferences did not change. Rather, the meaning of "conservative" and "liberal" changed (Lewis, 2020). It's not just that "liberal" Republicans and "conservative” Democrats vote contrary to what their party signaled as its policy preferences in the most recent political campaign, but that "conservative" Republicans and "liberal" Democrats do, too. Both partisan labels and ideological labels tell us who votes with whom, but neither tell us the policy substance of what they vote for.

\section{Political Reputations, Partisanship, and Public Policy}

One possible explanation for these paradoxical outcomes, examined in this paper, is that presidents and members of Congress are operating in a complex environment of political reputations, public opinion, and partisanship —in addition to acting on their ideal-point policy preferences. The pivotal politics model posits that ideology (or ideal-point preferences) are most important in determining policy outcomes, but this model leaves out not only the fact that policymakers are partisans (Lee, 2009), but also the fact that policymakers are operating within the 
constraints of their political reputations. Presidents and members of Congress care deeply about their approval ratings and public perceptions, which are shaped by those reputations. Moving "beyond ideology" (Lee, 2009), this paper demonstrates the importance of both political reputations and partisanship in determining public policy outcomes.

First, political reputations are important to consider because, ironically, parties and policymakers are often not trusted by the public to move policy in the direction of their reputation (and may be criticized as an "extremist" for doing so), but they often are trusted to move public policy in the opposite direction of their reputation. This logic is articulated in the famous phrase: "Only Nixon could go to China." Because he built his political reputation as an anti-communist in the House of Representatives during the Second Red Scare, President Richard Nixon could improve diplomatic relations with Communist China without being accused of being "soft on communism," while someone like Nixon's 1972 presidential election opponent, George McGovern, would not have been able to accomplish that same feat. Because of his reputation as a "radical, left-winger," McGovern would have been accused by Republicans of selling America out to communist China if he had attempted the same thing.

Second, partisanship is important to understand because members of Congress are much more likely to follow, and justify, the actions of a co-partisan president who moves public policy away from their signaled preferences than they are to follow the actions of a president from the opposing party who tries to move public policy away from their preferences (Lee, 2009). This logic can be seen at play at many points in American history. For example, Jeffersonian Republicans frequently voted against the Hamiltonian Federalist economic plan of tariffs, internal improvements, and a national bank when they were being proposed by Hamilton in the 1790s, but began to vote for many of these same policies when the "American System" was proposed by Republican presidents in the 1810s and 1820s (Adams, 1891; Croly, 1909; Beard, 1928). Similarly, Democrats in Congress 
frequently voted against President Herbert Hoover's interventions into the economy at the beginning of the Great Depression on the grounds that they centralized too much power in the national government in Washington, but began to vote for many of these same policies when the "New Deal” was proposed by Democratic President Franklin D. Roosevelt in the 1930s (Kennedy, 1999, p. 102) (Lewis, 2019). In the 1960s, many Republicans voted against Great Society programs on the grounds that they expanded the powers of the national government too much, and intervened too much in the economy, but began voting for many similar policies when they were proposed by Republican President Nixon in the 1970s.

These two factors help explain the puzzling finding that presidents are more likely to move public policy in the direction of their defeated political opponent's preferences than they are to sign legislation moving public policy toward their own signaled preferences. In the following sections, I will briefly analyze the important laws enacted during each of the past fifteen Congresses and five presidencies to see this logic at work.

\section{Public Policy During the Bush 41 Presidency}

The presidential election contest of 1988 was similar to the presidential campaigns of 1980 and 1984. The Republican presidential candidate, Vice President George H.W. Bush, called for a continuation of Reaganism by defending free markets, pursuing an anti-communist foreign policy, and promoting traditional morality. In a memorable line in his party nomination acceptance speech,

Bush assured voters of his Reaganite bona fides by saying that if he were president, unlike Dukakis, he would not raise taxes: “My opponent won't rule out raising taxes. But I will. And the Congress will push me to raise taxes and I'll say no. And they'll push, and I'll say no, and they'll push again, and I'll say, to them, 'Read my lips: no new taxes”' (Bush G. , 1988). Democratic candidate and Massachusetts Governor Michael Dukakis, on the other hand, called for increasing taxes and 
government spending on social programs. Dukakis responded to Bush's characterization of Dukakis as a "liberal" by describing himself as "a liberal in the tradition of Franklin Roosevelt and Harry Truman and John Kennedy" (Toner, 1988).

In addition to the candidates' speeches, the 1988 party platforms also signaled the public policy preferences of the two parties as being a contest between Reagan's “conservatism” and FDR's "liberalism." The 1988 GOP platform argued that limited government and individual freedom leads to opportunity, growth, and progress: "In 1984, we said 'From freedom comes opportunity; from opportunity comes growth; from growth comes progress.' In 1988, we reaffirm that truth. Freedom works. This is not sloganeering, but a verifiable fact. It has been abundantly documented during the Reagan-Bush Administration in terms of real jobs and real progress for individuals, families, and communities urban and rural. Our platform reflects on every page our continuing faith in the creative power of human freedom" (Republican National Convention, 1988). The 1988 Democratic Party platform, in contrast, argued that government programs should be used to ensure opportunity, growth, and progress: "All Americans have a fundamental right to economic justice in a stronger, surer national economy...We believe that...we can have a first-rate full employment economy, with an indexed minimum wage that can help lift and keep families out of poverty, with training and employment programs — including child care and health care — that can help people move from welfare to work, with portable pensions and an adequate Social Security System" (Democratic National Convention, 1988). During a time of economic prosperity, Bush's promises to continue Reaganism resonated with voters more than Dukakis' allegations against a corrupt administration. Bush won the popular vote $53 \%$ to $46 \%$. Many voters concerned about higher taxes presumably voted for Bush on the basis of his tax pledge. Likewise, many voters desiring a higher minimum wage presumably voted for Dukakis on the basis of the Democratic Party's pledge to increase it. 
According to David Mayhew (2019), during the Bush 41 administration, the Democratic $101^{\text {st }}$ and $102^{\text {nd }}$ Congresses passed 17 important laws: a minimum wage hike, a savings-and-loan bailout, a deficit reduction package, the Americans with Disabilities Act of 1990, the Clean Air Act of 1990, a child care bill, the Immigration Act of 1990, the National Affordable Housing Act of 1990, an agriculture bill, the Persian Gulf Resolution, the Surface Transportation Act of 1991, the Civil Rights Act of 1991, an omnibus energy act, a Strategic Arms Reduction Treaty, an economic aid package for ex-Soviet republics, a cable-TV regulation bill, and a California water policy bill. All but one was signed into law by President Bush (the cable-TV bill was passed through a veto override). Of these 17 laws, eleven moved policy in the Democrats' preferred direction, five did not clearly move policy in either party's favor (including the deficit reduction package that included a tax increase), and only one moved policy in the Republicans' preferred direction (the Persian Gulf Resolution). Given the reputation of Reagan's Republican Party, Bush possibly worried that vetoing Democratic bills would be seen as too extreme, intransigent, or "right-wing" by the voters he would face in his re-election bid. Perhaps assuming that his Republican base was secure, Bush had an incentive to try to attract Democratic voters for his 1992 re-election bid by signing into law Democratic policy priorities (Ceaser \& Busch, 1993, p. 33).

An alternative explanation for Bush's sixteen signatures could be that Bush was worried that Democrats would simply override his veto with more extreme legislation favoring their policy preferences if he did not compromise and sign. However, this explanation is unsatisfactory: Democrats never had more than 55 votes in the Senate or 267 votes in the House. Any veto overrides for "extremely liberal" legislation would have required a lot of Republican defections with no Democratic defections.

Even though American voters overwhelmingly supported Reagan Republicanism in the 1988 presidential election (Bush won 40 of 50 states), American public policy moved overwhelmingly in 
the direction signaled by Democrats following that election (11of 12 important laws that moved the status quo). The national government seemingly would have enacted very similar legislation whether the president was Bush or Dukakis. It's even conceivable that a President Dukakis would not have gone as far as Bush did in hopes of reassuring 1992's re-election voters that he was a moderate liberal of the FDR, Truman, and JFK variety rather than a "radical" liberal of the McGovern or Mondale variety.

\section{Public Policy During the Clinton Presidency}

Having moved public policy in the direction of the preferences signaled by Michael Dukakis, President Bush lost support from many Republicans and, in running for re-election, had to fight off a primary challenge from "conservative" columnist and TV personality Pat Buchanan, who accused Bush of moving the country "in a liberal direction” (Allen, 1992). On the Democratic side, after three consecutive losses in presidential elections, the Party nominated a "New Democrat" in 1992. Bill Clinton was a leader of the Democratic Leadership Council and presented himself as more moderate than his losing predecessors. As a result, the stark contrast offered in the 1980s seemed less clear in 1992 - particularly with independent candidate Ross Perot muddying the waters.

Nonetheless, despite his "betrayals," self-identifying conservatives largely rallied to the cause of the Republican candidate and self-identified liberals largely rallied to the cause of the Democratic candidate (Roper Center, 1992). In his 1992 GOP Convention speech, Bush asked Republicans to forgive him for his policies: "It was a mistake to go along with the Democratic tax increase, and I admit it. But here's the question for the American people. Who do you trust in this election? The candidate who's raised taxes one time and regrets it, or the other candidate who raised taxes and fees 128 times and enjoyed it every time? ... I believe that small business needs relief from taxation, regulation, and litigation. And thus, I will extend for one year the freeze on paperwork and 
unnecessary Federal regulation that I imposed last winter” (Bush G. , 1992). The Republican presidential candidate campaigned on free trade, less spending, lower taxes, and school choice (Bush G. , 1992). Clinton campaigned on a "New Covenant" with the American people, and his 1992 party platform called for a new "third way" in politics: "a radical change in the way government operates - not the Republican proposition that government has no role, nor the old notion that there's a program for every problem, but a shift to a more efficient, flexible and results-oriented government that improves services, expands choices, and empowers citizens and communities to change our country from the bottom up. We believe in an activist government, but it must work in a different, more responsive way" (Democratic National Convention, 1992).

After winning the election, President Clinton seemingly abandoned the "New Covenant" and, with unified control of government, pursued more traditional Democratic policy priorities (Krehbiel, 1998, p. 29). When he attempted to reform the American health care system to ensure universal health coverage, Republicans — repenting of their previous votes to expand government during the Bush 41 administration—found religion and mobilized against "HillaryCare," which became so unpopular that the Democratic Congress gave up on it. Nonetheless, Clinton went on to work with the $103^{\text {rd }}$ Democratic Congress to sign twelve major laws, including a deficit reduction act, NAFTA, the Family and Medical Leave Act of 1993, the Motor Voter Act, the National Service Act, the Brady Bill, and the 1994 crime bill. Despite Democratic control of unified government, only five of these twelve important laws moved public policy in the direction of Democratic Party preferences. Four of the laws did not move public policy in either direction and, surprisingly, three of them moved public policy in the direction of the preferences of Republicans who were entirely shut out of the national government.

In the 1994 midterm elections, the Republican Party won control of Congress for the first time in over 40 years by campaigning for less government intervention and more free markets, and 
President Clinton faced a Republican House and Senate for his next six years in office. Under these circumstances, we might expect an even draw between the two parties, but the 30 important laws passed during that period mostly moved public policy in the direction signaled by Republicans (14 laws) rather than Democrats (only 4 laws). For example, the 1996 welfare reform bill replaced the AFDC program with the TANF program, and helped Republicans achieve a policy victory they had been fighting for over the previous several decades. The Telecommunications Act of 1996 also fulfilled Republicans' many calls for deregulation. In fact, Republicans were far more successful in cutting government regulations and spending during the Clinton administration than at any time in the past century when they have had unified control of government. Strangely, Republicans in control of Congress will shrink government if they can get a Democratic president to go along with it, but not if the president is a Republican.

Clinton, a savvy political operator, always had his eye on his approval ratings, and he tried hard to not let his political opponents paint him as a "liberal extremist." After the failure of his health care reform efforts, and other "liberal" policy proposals during his first year in office, Clinton tacked hard to his "third way" to win approval and votes (Nelson \& Milkis, 2019). Accepting that "the era of big government [was] over," under the Democratic president, public policy consistently moved in the preferred direction signaled by losing Republican presidential candidates. Ironically, Reaganites who called for less government spending, balanced budgets, and welfare reform got much more of what they wanted during the Clinton administration than they ever got during the Reagan or Bush administrations. However, in the following decade, public policy consistently moved in the preferred direction signaled by Democrats. 


\section{Public Policy During the Bush 43 Presidency}

The 2000 presidential campaign sounded familiar themes in which "conservative" Republicans argued for lower taxes and less spending (while adding a call for a less interventionist foreign policy) and "liberal" Democrats called for more government regulation of corporations and spending on social programs to help ordinary Americans. Gore won the "liberal" vote 81-13 and Bush won the "conservative" vote 82-17 (Roper Center, 2000). The 2000 GOP platform argued that the Republican Party represented "the founding principles of freedom and limited government" (Republican National Convention, 2000). As an expression of these principles, the platform called for cutting taxes, argued that reducing the "debt is both a sound policy goal and a moral imperative," and criticized "bailouts of corrupt officials and risk-taking investors." In his party nomination acceptance speech, Bush argued that "big government is not the answer, but the alternative to bureaucracy is not indifference. It is to put conservative values and conservative ideas into the thick of the fight for justice and opportunity" (Bush G. W., 2000). In his own acceptance speech, Vice President Gore promised to use the powers of the executive branch to provide "a prescription drug benefit for all seniors under Medicare... I'll fight for it and the other side will not." He also promised to use the power of the national government to fight "against big polluters," "to rebuild...schools and to reduce class size," and "for affordable health care for all" (Gore, Jr., 2000).

During his two terms in office, President Bush enacted many of the policies that Gore warned voters only the Democratic candidate would enact. The 2002 No Child Left Behind Act, coauthored by Sen. Ted Kennedy (D-MA), re-authorized the Great Society Era's Elementary and Secondary Education Act and increased federal government spending on education by an astounding 60\% even though Bush had campaigned on less federal spending and states' rights. The 2002 Farm Bill increased government spending on farm subsidies by billions of dollars to encourage the farming of certain agricultural products even though the 2000 GOP platform argued that 
farmers "can do for themselves far better than anything government can do for them...They want to produce what makes sense on their own private property, not what official Washington thinks should be grown there" (Republican National Convention, 2000). Republicans in Congress gave President Bush extensive powers to prosecute war in the Middle East even though Republicans had criticized Vice President Gore for the Clinton administration's foreign interventionism. In the 2000 presidential debates, Bush pointed to his own "humble foreign policy," that would not send the American military around the world, as one of the most important distinctions between the two candidates (Lewis, 2017).

It is probable that if Bush had showed restraint in using the American military, as he had promised to do (and as Republicans had claimed they wanted Clinton to do in the 1990s), in response to the 9/11 attacks, there would have been public backlash from many Americans who wanted revenge for the Islamist terrorist attack on American soil. The 2001 Authorization for the Use of Military Force was approved almost unanimously by both parties and both houses of Congress. As the wars turned sour, Bush's approval ratings gradually came back down, and perhaps he thought he could shore up Democratic support by pushing through Congress domestic policies that we would have expected from a Democratic president, including — in addition to the very expensive education and health care laws—an airline bailout, a $\$ 40$ billion emergency spending bill, the Sarbanes-Oxley Act, and the AIDS funding bill. Since Bush was a "conservative," Republicans in Congress went along with these proposals and nobody accused him of being a "left-wing" "socialist" when he proposed dramatically increasing government spending, debt, and regulationsas they no doubt would have if a President Gore had proposed the same measures. Ironically, Democrats got much more of what they claimed they wanted in the 2000 presidential campaign by losing, rather than winning, Bush v. Gore, Florida, and the Electoral College. Republicans, on the other hand lost the policy fight by winning the election. 
After winning re-election in 2004, and winning control of unified government, Bush and the Republican Congress enacted some expected laws (e.g., the Class Action Fairness Act, a free trade agreement, and postal service reform), but also increased spending and expanded the size of government in ways that John Kerry would have wanted. After Democrats won back control of Congress in the 2006 midterm elections, Bush signed a series of bills pushing public policy in the direction of Democratic Party preferences, including a minimum wage hike, an overhaul of college student aid programs, a housing relief program, and a $\$ 700$ billion government bailout. Once again, it is unlikely that Republicans in Congress would have gone along with these measures if they had been proposed by a President Kerry. However, since they were proposed by President Bush, Republicans voted overwhelmingly to move public policy in the direction of Democratic Party preferences.

Of the 53 important laws enacted during the George W. Bush presidency, only 15 of them moved public policy in the direction signaled by Bush in the 2000 and 2004 presidential campaigns. 14 did not move public policy in either party's direction, but an astounding 34 laws moved public policy in the direction signaled by Al Gore and John Kerry in their losing presidential campaigns. A few of these laws were passed when Bush faced a unified Democratic 109th Congress (one of them was the result of a veto override), but many more were passed when Congress was divided (Republicans had decisive control in the House and Democrats had a narrow majority after Sen. Jim Jeffords began caucusing with Democrats). 6 of them, in fact, were passed when Republicans had unified control of government. Based on presidential campaign rhetoric and party platforms, Democrats generally got what they said they wanted during the two Bush administrations and Republicans generally got what they said they wanted during the two Clinton administration. 


\section{Public Policy During the Obama Presidency}

Despite the policy production of the two parties during the previous 20 years-federal social programs, spending, and deficits expanding under Republican presidents and shrinking under a Democratic president — the 2008 presidential campaign featured the same familiar rhetoric:

Republicans vowed to cut back on the size and scope of government to promote individual liberty while Democrats promised to use government spending and taxes to promote socioeconomic equality. In his party nomination acceptance speech, Barack Obama criticized John McCain for subscribing "to that old Republican philosophy" of laissez faire, which is unwilling to spend money on social programs: "Out of work? Tough luck. No health care? The market will fix it. Born into poverty? Pull yourself up by your own bootstraps - even if you don't have boots. You're on your own" (Obama, 2008). McCain described the differences between the two parties in this way: "We believe in low taxes, spending discipline, and open markets... I will open new markets to our goods and services. My opponent will close them. I will cut government spending. He will increase it. My tax cuts will create jobs; his tax increases will eliminate them... Reducing government spending and getting rid of failed programs will let you keep more of your own money to save, spend, and invest as you see fit" (McCain, 2008).

In the election, with an unpopular War on Terror overseas and a cratering economy at home, Americans decisively repudiated the Republican administration in the voting booth. Obama took office with unified control of government and Democrats moved public policy in the expected ways, including a $\$ 787$ billion stimulus measure, the Lily Ledbetter Fair Pay Act, a credit card bill of rights, tobacco regulation, financial services regulation, and the repeal of "Don't Ask Don't Tell."

Obama's signature piece of legislation, the Affordable Care Act, increased government spending on health care-although he did so by following a policy proposal from the Heritage Foundation and a policy model from Romneycare. 
After Republicans took back control of the House of Representatives in 2011, the two parties, unable to agree on government spending levels, faced off in a series of "fiscal cliffs." Republican MCs, now opposing a Democratic president, once again repented of their profligate ways and began resisting government spending increases. After taking control of the Senate in 2015, they even managed to get Obama to sign a $\$ 680$ billion tax cut package. Overall, however, Obama moved public policy in the direction he signaled in his 2008 and 2012 campaigns. Of the 45 important laws Obama signed while in office, 25 moved policy in the direction of the preferences signaled by the Democratic Party during the campaigns, while only 6 moved public policy in the direction signaled by Mitt Romney and the GOP in his 2012 presidential campaign.

\section{Public Policy During the Trump Presidency}

The 2016 presidential campaign between Donald Trump and Hillary Clinton, although extraordinary in American history, sounded many familiar themes from the previous quartercentury. Although Trump called for protectionist trade policy, the rest of his campaign promiseson immigration, health care, abortion, federal spending, taxes, and deficits — signaled a desire to move American public policy in the direction signaled by the Republican Party during the Obama administration. On the campaign trail, Trump promised to build a wall on the southern border and

make Mexico pay for it. He promised to erase America’s $\$ 19$ trillion national debt over the course of his eight-year presidency (Woodward \& Costa, 2016). He called for a ban on immigration by Muslims, a repeal of Obamacare, and the imprisonment of women who have an abortion. The 2016 GOP platform echoed Trump's call for fiscal restraint and responsibility: "Our national debt is a burden on our economy and families. The huge increase in the national debt demanded by and incurred during the current Administration has placed a significant burden on future generations. We must impose firm caps on future debt, accelerate the repayment of the trillions we now owe in 
order to reaffirm our principles of responsible and limited government, and remove the burdens we are placing on future generations. A strong economy is one key to debt reduction, but spending restraint is a necessary component that must be vigorously pursued" (RNC, 2016).

As a more conventional candidate, Clinton also made proposals moving public policy in the direction of the preferences signaled by Democrats during the previous two decades. The 2016 party platform called for an increased minimum wage, more labor unionization, more generous family and medical leave requirements, corporate profit-sharing, increased funding for government housing programs, an expansion of Social Security benefits, higher taxes on the wealthy, more infrastructure spending, more regulation of Wall Street, stronger antitrust regulation, removal of the Confederate flag from public institutions, farm subsidies, campaign finance reform, stronger environmental regulations, free college for low-income families, Medicare expansion, and increased funding for the National Institutes of Health and the Centers for Disease Control and Prevention (DNC, 2016).

Despite losing the popular vote by three million votes, Trump won the Electoral College and Republicans retained control of Congress. Trump's record with unified government was mixed. Republicans enacted almost as many important laws moving public policy in the direction signaled by Clinton in the campaign (five) as they did laws moving public policy in the direction signaled by Trump (six). Republicans enacted some predictable laws, including a tax cut, deregulation, repeal of the ACA's individual mandate, and authorization of arctic drilling. However, they also increased federal spending by $\$ 7$ billion on a drug addiction treatment program, by $\$ 140$ billion on disaster relief, and by $\$ 867$ billion on farm subsidies and food stamps. Republicans abandoned the spending caps established by the Budget Control Act of 2011, and they passed a criminal justice reform law to reduce incarceration. It is unlikely that Republicans would have supported these bills if they had been proposed by a President Hillary Clinton, and chants of "Lock Her Up!" would probably have been still ringing at Republican political rallies. After the 2018 midterm elections, with Congress 
divided, President Trump worked with Senator McConnell to pass an unprecedented \$2.2 trillion stimulus bill. As mentioned at the outset, it is almost impossible to imagine that Republicans in Congress would have passed such a bill if Clinton had been president at that time.

\section{Conclusion}

In general, the party that loses a presidential election tends to achieve more of its policy objectives. This outcome cannot be explained by theories of policymaking that focus solely on party and ideology, but they can be explained by focusing on political reputations and public opinion. Often, Democrats enact laws that decrease government size and spending to woo voters in the upcoming election and preempt charges that they are "tax-and-spend liberals." Likewise, Republicans often enact laws that increase government regulations, spending, and deficits to woo voters in the upcoming election and preempt charges that they are "heartless conservatives."

It seems that, because presidents are worried about their approval ratings, they pay close attention to electoral mandates. If the public hands them unified control of government, they pursue the policies they signaled in the campaign to some degree, but if the public hands them a Congress controlled by the opposition party, they will sign a raft of legislation pushing public policy in the direction signaled by the Congressional party in the campaign (even when that party has nowhere near enough votes for a veto override). If the public hands them a divided Congress, they are more likely to sign legislation moving policy in the direction of their opposition party than their own party. Republican presidents, perhaps trying to win over Democratic voters, almost never abolish government agencies or decrease federal spending, but they do increase it. Clinton and Obama, perhaps trying to win over Republican voters, signed laws decreasing government spending, but neither Bushes nor Trump ever did—even in the Congresses when they controlled unified government. 
Partisanship also seems to matter a great deal. Democrats are willing to cut government spending if their president proposes it, but they will resist spending cuts if a Republican proposes it. Likewise, Republicans are willing to vote for stimulus bills if their president proposes it, but they will resist stimulus bills proposed by a Democratic president. Democrats are more likely to support a war in Iraq prosecuted by a Clinton than a Bush. Republicans criticized the foreign interventionism of the Clinton administration but celebrated the foreign interventionism of the Bush administration.

These results challenge the claim made by political scientists that policymakers have particular ideal preference points, in ideological space, discernible from rhetoric on the campaign trail and votes in office. It seems that politicians' preference points are extremely flexible based on public opinion and institutional context. We should not model policymaking with the assumption that policymakers are strategic actors with fixed ideological preference points because those preference points are not actually fixed. All of the formal models of policymaking that rely on ideological scores derived from roll-call scaling applications are actually post-hoc explanations of the policymaking process. They pretend that a roll-call vote "reveals" a policymaker's ideological ideal preference point when in reality the preference point is constantly evolving and subject to the institutional context.

These results also challenge the argument made by partisans that it is worth voting for a corrupt or authoritarian politician if that candidate signals issue positions close to the voter's ideal preference points. In truth, a candidate's preference points are evolutionary and subject to public opinion and institutional context. ${ }^{4}$ Due to the nature of political reputations, voters are just as likely to get the policy they want from the opposing party as they are from their own party. As a result, voters should feel free to unplug their noses.

\footnotetext{
${ }^{4}$ Many voters - like the candidates they vote for-also do not have fixed ideological preference points. As recent scholarship has pointed out, partisans are constantly switching their issue positions based on the changing cues they receive from their party's leaders (Barber \& Pope, 2019).
} 


\section{WORKS CITED}

Adams, H. (1891). History of the United States of America during the First Administration of Thomas Jefferson (Vol. 2). New York: Scribner.

Allen, H. (1992, February 17). The Iron Fist of Pat Buchanan. The Washington Post.

Barber, M., \& Pope, J. C. (2019, February). Does Party Trump Ideology? Disentangling Party and Ideology in America. American Political Science Review, 113(1), 38-54.

Beard, C. A. (1928). The American Party Battle. New York: Workers Education Bureau Press, Inc.

Busch, A. E., \& Ceaser, J. W. (2002). The Perfect Tie: The True Story of the 2000 Presidential Election. Lanham, MD: Rowman \& Littlefield Publishers.

Bush, G. (1988, August 18). Address Accepting the Presidential Nomination at the Republican National Convention in New Orleans. Retrieved May 2020, from The American Presidency Project: presidency.ucsb.edu/documents/address-accepting-the-presidential-nomination-therepublican-national-convention-new

Bush, G. (1992, August 20). Remarks Accepting the Presidential Nomination at the Republican National Convention in Houston. Retrieved August 2010, from The American Presidency Project: https://www.presidency.ucsb.edu/node/266944

Bush, G. W. (2000, August 3). Address Accepting the Presidential Nomination at the Republican National Convention in Philadelphia. Retrieved August 2020, from The American Presidency Project: https://www.presidency.ucsb.edu/node/211699

Ceaser, J. W., \& Busch, A. (1993). Upside Down and Inside Out: The 1992 Elections and American Politics. Lanham, MD: Rowman \& Littlefield Publishers.

Croly, H. (1909). The Promise of American Life. Norwood, MA: Norwood Press.

Democratic National Convention. (1988, July 18). 1988 Democratic Party Platform. Retrieved May 2020, from The American Presidency Project:

https://www.presidency.ucsb.edu/documents/1988-democratic-party-platform

Democratic National Convention. (1992, July 13). 1992 Democratic Party Platform. Retrieved August 2020, from The American Presidency Project: https://www.presidency.ucsb.edu/node/273264

Democratic National Convention. (2016, July 21). 2016 Democratic Party Platform. Retrieved from The American Presidency Project : https://www.presidency.ucsb.edu/node/318309

Downs, A. (1957). An Economic Theory of Democracy. New York: Harper and Row.

Fiorina, M., \& Abrams, S. (2009). Disconnect: The Breakdown of Representation in American Politics. Norman: University of Oklahoma Press. 
Gore, Jr., A. (2000, August 17). Address Accepting the Presidential Nomination at the Democratic National Convention in Los Angeles. Retrieved August 2020, from The American Presidency Project: https://www.presidency.ucsb.edu/node/216697

Grossman, M. (2014). Artists of the Possible: Governing Networks and American Policy Change Since 1945. New York: Oxford University Press.

Hacker, J. S., \& Pierson, P. (2014, September). After the "Master Theory": Downs, Schattschneider, and the Rebirth of Policy-Foucsed Analysis. Perspectives on Politics, 12(3), 643-662.

Hinich, M. J., \& Munger, M. C. (1994). Ideology and the Theory of Political Choice. Ann Arbor: University of Michigan Press.

Hopkins, D. J., \& Noel, H. (2017, August 24). Is John McCain more conservative than Rand Paul? Using activists' pairwise comparisons to measure ideology. Retrieved from hansnoel.com

Kennedy, D. M. (1999). Freedom From Fear: The American People in Depression and War, 1929-1945. New York: Oxford University Press.

Krehbiel, K. (1998). Pivotal Politics: A Theory of U.S. Lawmaking. Chicago: University of Chicago Press.

Lee, F. E. (2009). Beyond Ideology: Politics, Principles, and Partisanship in the U. S. Senate. Chicago: University Of Chicago Press.

Lewis, V. (2017, March). The President and the Parties' Ideologies: Party Ideas about Foreign Policy Since 1900. Presidential Studies Quarterly, 47(1), 27-61.

Lewis, V. (2019). Ideas of Power: The Politics of American Party Ideology Development. New York: Cambridge University Press.

Lewis, V. (2020). The Problem of Donald Trump and the Static Spectrum Fallacy. Party Politics.

Mayhew, D. (1991). Divided We Govern: Party Control, Lawmaking, and Investigations, 1946-1990. New Haven: Yale University Press.

Mayhew, D. (2019, January 1). Datasets and Materials: Divided We Govern. Retrieved May 2020, from David Mayhew: http://campuspress.yale.edu/davidmayhew/datasets-divided-we-govern/

McCain, J. (2008, September 4). Address Accepting the Presidential Nomination at the Republican National Convention in Saint Paul. Retrieved from The American Presidency Project: https://www.presidency.ucsb.edu/node/279091

Nelson, M., \& Milkis, S. M. (2019). The American Presidency: Origins and Development, 1776-2018. Washington, DC: CQ Press.

Obama, B. (2008, August 28). Address Accepting the Presidential Nomination at the Democratic National Convention in Denver: "The American Promise". Retrieved from The American Presidency Project : https://www.presidency.ucsb.edu/node/278860

Poole, K. T., \& Rosenthal, H. (2006). Ideology and Congress: A Political Economic History of Roll Call Voting. London: Transaction Publishers. 
Republican National Convention. (1988, August 16). Republican Party Platform of 1988. Retrieved May 2020, from The American Presidency Project:

https://www.presidency.ucsb.edu/documents/republican-party-platform-1988

Republican National Convention. (2000, July 31). 2000 Republican Party Platform. Retrieved August 2020, from The American Presidency Project:

https://www.presidency.ucsb.edu/node/273446

Republican National Convention. (2016, July 8). 2016 Republican Party Platform. Retrieved from The American Presidency Project : https://www.presidency.ucsb.edu/node/318311

Roper Center. (1992, November). How Groups Voted in 1992. Retrieved from Roper Center for Public Opinion Research: https://ropercenter.cornell.edu/how-groups-voted-1992

Roper Center. (2000, November). How Groups Voted in 2000. Retrieved from Roper Center for Public Opinion Research: https://ropercenter.cornell.edu/how-groups-voted-2000

Sladin, R. P., \& Teles, S. M. (2020). Never Trump: The Revot of the Conservative Elites. New York: Oxford University Press.

Toner, R. (1988, October 31). Dukakis Asserts He Is a 'Liberal,' But in Old Tradition of His Party. The New York Times, p. A1.

Woodward, B., \& Costa, R. (2016, April 2). In a revealing interview, Trump predicts a 'massive recession' but intends to eliminate the national debt in 8 years. The W ashington Post. 


\section{Appendix 1: Important Laws since 1989}

\begin{tabular}{|c|c|c|c|c|}
\hline Congress & $\begin{array}{l}\text { Year } \\
\text { Signed }\end{array}$ & President & *All caps indicates a historically important law & $\begin{array}{l}\text { Expected }(1), \\
\text { Unexpected }(0) \text {, } \\
\text { or neither }(-)\end{array}$ \\
\hline \multirow[t]{9}{*}{101 st } & 1989 & Bush & Minimum wage hike & 0 \\
\hline & & & Savings-and-loan bailout & 0 \\
\hline & 1990 & & DEFICIT REDUCTION PACKAGE & - \\
\hline & & & Americans with Disabilities Act of 1990 & 0 \\
\hline & & & Clean Air Act of 1990 & 0 \\
\hline & & & Child care package & 0 \\
\hline & & & Immigration Act of 1990 & 0 \\
\hline & & & National Affordable Housing Act of 1990 & 0 \\
\hline & & & Agriculture act & - \\
\hline \multirow[t]{8}{*}{ 102nd } & 1991 & Bush & PERSIAN GULF RESOLUTION & 1 \\
\hline & & & Surface transportation act (ISTEA) & 0 \\
\hline & & & Civil Rights Act of 1991 & 0 \\
\hline & 1992 & & Omnibus energy act & 0 \\
\hline & & & Strategic Arms Reduction Treaty & - \\
\hline & & & Economic aid package for ex-Soviet republics & - \\
\hline & & & Cable-TV regulation & 0 \\
\hline & & & California water policy & - \\
\hline \multirow[t]{13}{*}{$103 \mathrm{rd}$} & 1993 & Clinton & OMNIBUS DEFICIT REDUCTION ACT & - \\
\hline & & & NORTH AMERICAN FREE TRADE & \\
\hline & & & AGREEMENT & 0 \\
\hline & & & Family and Medical Leave Act of 1993 & 1 \\
\hline & & & Motor Voter act & - \\
\hline & & & National Service act & 1 \\
\hline & & & Reform of college-student loan financing & - \\
\hline & & & Brady bill & 1 \\
\hline & 1994 & & Goals 2000 & - \\
\hline & & & Omnibus crime act & 0 \\
\hline & & & California desert protection & 1 \\
\hline & & & Abortion clinic access & 1 \\
\hline & & & General Agreement on Tariffs and Trade & 0 \\
\hline \multirow[t]{5}{*}{ 104th } & 1995 & Clinton & Curb on unfunded mandates & - \\
\hline & & & Congressional Accountability Act & - \\
\hline & & & Lobbying reform & - \\
\hline & & & $\begin{array}{l}\text { Curb on shareholder lawsuits. To curb frivolous } \\
\text { suits against flagging firms. Over Clinton's veto }\end{array}$ & 0 \\
\hline & 1996 & & WELFARE REFORM. & 0 \\
\hline
\end{tabular}


TELECOMMUNICATIONS REFORM

Agriculture deregulation $\quad 0$

Line-item veto 0

Anti-terrorism act 0

\$24 billion spending cuts in 1996 budget deal 0

Health insurance portability act

Minimum wage hike

Overhaul of pesticides regulation

Overhaul of safe drinking water legislation

Immigration reform

1997 Clinton BALANCE THE BUDGET BY 2002 DEAL 0

Chemical Weapons Convention ratified

Overhaul of Food and Drug Administration $\quad 0$

Adoption of foster children

1998

Transportation construction act

Overhaul of Internal Revenue Service $\quad 0$

NATO expansion ratified

Reform of public housing 100,000 new school teachers.

106th Clinton Banking reform 1999

Y2K planning

Ed-flex program 0

$2000 \quad$ Permanent Normal Trading Relations 0

Florida Everglades restoration act 1

Community Renewal and New Markets Act 1

107th 2001 Bush BUSH TAX CUT. \$1.35 trillion over 10 years 1

USE OF FORCE RESOLUTION 0

USA PATRIOT ACT

Airline bailout 0

Airline security 0

$\$ 40$ billion emergency spending 0

Education reform 0

IRAQ RESOLUTION 0

NEW HOMELAND SECURITY

DEPARTMENT

Campaign finance reform 0

Agriculture subsidies 0

Corporate Responsibility Act 0

Fast-track trade authority -

Election reform 0 


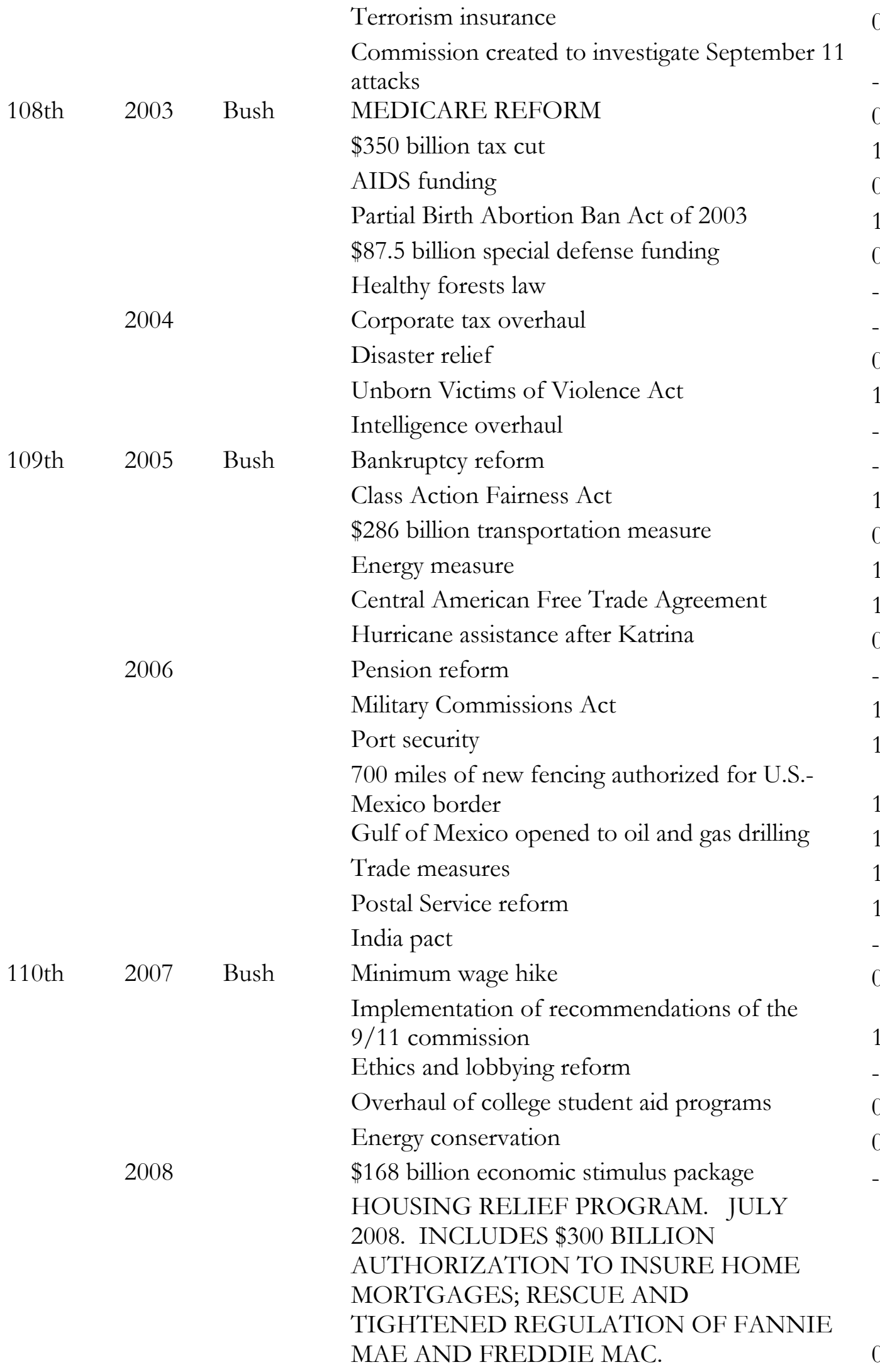


\$700 BAILOUT OF THE FINANCIAL

SECTOR. OCTOBER 2008. COMBINED

WITH \$150 BILLION IN TAX BREAKS

0

Agriculture subsidy bill

Domestic surveillance

New G.I. bill for veterans

Nuclear trade agreement with India

Guarantee of mental illness insurance

$2009 \quad$ Obama

*\$787 BILLION STIMULUS MEASURE TO

JUMP-START THE ECONOMY

Expansion of State Children's Health Insurance

Program

Lilly Ledbetter Fair Pay Act

Credit card bill of rights

Tobacco regulation

Expansion of national and community service programs

Expansion of hate crimes law

Public lands preservation

2010

112th $2011 \quad$ Obama

2012

AFFORDABLE CARE ACT

FINANCIAL SERVICES REGULATION

Student loan overhaul

BIPARTISAN TAX DEAL

New START treaty ratified

Repeal of 'Don't Ask, Don't Tell

Regulation of food safety

Help to 9/11 first responders

DEBT CEILING DEAL

Modernization of patent law

Trade agreements with Colombia, Panama,

South Korea

Ban on insider trading by members of Congress 2012

Jumpstart Our Business Startups (JOBS) Act

Normalization of trade relations with Russia

FISCAL CLIFF DEAL

113th 2013 Obama Superstorm Sandy aid

Violence Against Women Act

Overhaul of student loan program

Curb sexual assaults in the military

Agriculture program 
Water Resources Reform and Development Act (WRRDA)

Overhaul of Department of Veterans Affairs

Arm and equip Syria rebels to fight against ISIL 0

Flexibility for multi-employer pension plans 0

Campaign finance loosening

114th 2015 Obama Permanent fix to Medicare's sustainable growth rate formula

Fast-track trade authorization to president to negotiate agreements with Asia and Europe USA Freedom Act

Two-year budget deal lifting domestic and defense spending caps

Overhaul of No Child Left Behind

Five-year transportation infrastructure plan 1

$\$ 680$ billion tax-cut package 0

Lift of 1920s-era ban on oil exports $\quad 0$

2016

115th $2017 \quad$ Trump

Opioids policy

Puerto Rico debt relief

21st-Centurry Cures Act

Water Resources and Development Act (WRDA)

TAX REFORM

SIXTEEN EXECUTIVE REGULATIONS REPEALED THROUGH USE OF THE CONGRESSIONAL REVIEW ACT (CRA) 1

Reform of Department of Veterans Affairs

Disaster relief totaling some $\$ 140$ billion

Repeal of the Affordable Care Act's individual mandate

Authorization of Arctic drilling in Alaska

Abandonment of spending caps established by the Budget Control Act of 2011

Relaxation of Dodd-Frank regulations regarding small banks

Reform of Veterans Affairs Department to allow privatization of care

Five-year $\$ 867$ billion agriculture and foodstamps package

Criminal justice reform 